\title{
Trend Analyses of Parameters of Equations for Maximum CBR Distance Achievable in Ubicomp MANETs Using Location-Aware Transmission.
}

\author{
M. Kaleem GALAMALI, Assoc. Prof Nawaz MOHAMUDALLY
}

\begin{abstract}
MANET transmission strategies represent one key to address the problem of scarce network amenities in ubicomp topographies. It is understandable that correctly designed protocols for this work can help in controlling energy issues in ubicomp [78]. The enforcement of location-aware transmission strategies is augured to enhance energy management and hence deserves all effort put in by researchers. A few enhancements awaited are: the application of land-based GPS systems, improved location refresh rates and accuracy, development of refined protocols optimised for transmission according to distance and direction criteria, and development of cheaper hardware to support such functionalities. The knowledge of distance coverages by transmitted packets in a ubicomp and corresponding tendencies over different node densities, is undoubtedly favourable for fine tuning transmission protocols in MANETs. Such a corresponding empirical study was conducted in a former paper [27], whereby the metric Max_CBR_Dist was depicted.
\end{abstract}

In this paper, the next level of study needed for metric Max_CBR_Dist is stated as: "What are the trends of variation observable within each parameter of the equations of curves obtained for metric Max_CBR_Dist [27] over varying node densities?" Designers may potentially use the output detailed here, towards formulation of better ubicomp transmission protocols. This piece of research dwells a follow-up of previous research [1-42].

Key terms: Ubicomp- Ubiquitous Computing, MAUCMobile and Ubiquitous Computing, MANET- Mobile Adhoc Network, CBR- Constant Bit Rate, Max_CBR_Dist - Maximum CBR Distance.

M. Kaleem GALAMALI, University of Technology Mauritius (student) Mauritius

Assoc. Prof Nawaz Mohamudally

University of Technology Mauritius,

Mauritius

\section{Introduction}

Ubicomp topographies, especially those located outdoor or in poor countries, may be scantly equipped with network routing devices. Ubicomp topographies may also be very heterogeneous in features like accuracy level of distance measurement, location refresh rates and level of sophistication and update of operating protocols. MANET transmission may be the favourable choice for such spots. This may be augmented with location-aware transmission. Methods of studying the observable distance related features experienced by CBRs in ubicomp exist in large variety. Following a previous paper [26], a derivative method was explained [27], in which the pattern of metric Max_CBR_Dist was explained as following the normal distribution of form:

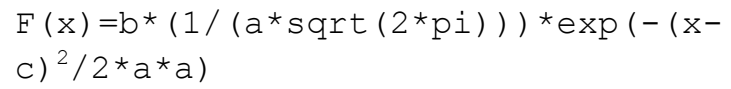

Here, the equations of the model have necessitated 3 parameters: $a, b$ and $c$. the next empirical formulation required for metric Max_CBR_Dist is the model equations for parameters of equation specified above.

The key contributions of this paper is the development of equations of trend of variations for each parameter of the equations involved for the model for metric Max_CBR_Dist presented previously [27] from which table 1 is re-exploited here. The empirical methods developed here remain at the disposal of designers and programmers, to be implemented into software simulators, giving rise to a tool assisting in more advanced investigations of the evolution and predictability of distance features in future ubicomp. The rest of this paper is organised as follows: section 2Parameter Trend Analysis- Metric Max_CBR_Dist, section 3- Conclusion and References.

\section{Parameter Trend Analysis - Metric Max_CBR_Dist.}

\subsection{General Procedure Adopted.}

The procedure adopted consist of breaking the work required into four stages as follows:

i. Plot the tabulated data for each parameter of the equation for the model for Max_CBR_Dist onto gnuplot.

ii. Graphical analyses are performed and general observations are noted.

iii. Different equations of fit are noted. Best fit is based on values of least reduced chi-square and 
Proc. of the Seventh International Conference On Advances in Computing, Electronics and Electrical Technology - CEET 2017. Copyright (C) Institute of Research Engineers and Doctors. All rights reserved.

ISBN: 978-1-63248-126-9 doi: 10.15224/ 978-1-63248-126-9-16

most appreciable extendability at node numbers 80 , 100 and 120.

iv. The parameter values for each Max_CBR_Dist parameter of equation is noted.

\subsection{Trend Analysis - Max_CBR Dist parameter " $a$ ".}

Generally the trend observed is an oscillation along a straight line (as axis) with positive gradient and not along a horizontal line.

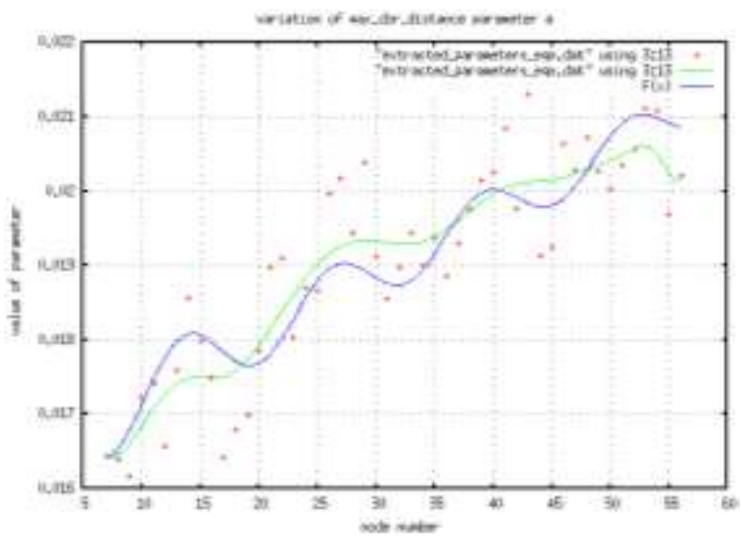

Figure 1: Max_CBR_Dist parameter a

The potentially applicable equations of best fit are:

$$
\begin{aligned}
& \text { 1. } F(x)=d * x+f \\
& \text { Ch_sq }=5.34867\left(\mathrm{e}^{-07}\right) \quad \mathrm{F}(80)=0.023103283 \\
& \mathrm{~F}(100)=0.024785033 \quad \mathrm{~F}(120)=0.026466783 \\
& \text { 2. } F(x)=a * \sin ((b * x)+c)+d * x+f \\
& \text { Ch_sq }=4.88808\left(\mathrm{e}^{-07}\right) \quad \mathrm{F}(80)=0.023014825 \\
& \mathrm{~F}(100)=0.024810030 \quad \mathrm{~F}(120)=0.025949942 \\
& \text { 3. } F(x)=a^{*} x * \sin ((b * x)+c)+d * x+f \\
& \text { Ch_sq }=5.22423\left(\mathrm{e}^{-07}\right) \quad \mathrm{F}(80)=0.022685099 \\
& \mathrm{~F}(100)=0.025560 \quad \mathrm{~F}(120)=0.025489111 \\
& \text { 4. } F(x)=(a / x) * \sin ((b * x)+c)+d * x+f \\
& \text { Ch_sq }=4.89641\left(\mathrm{e}^{-07}\right) \quad \mathrm{F}(80)=0.022927 \\
& \mathrm{~F}(100)=0.024587 \quad \mathrm{~F}(120)=0.026088 \\
& 5 . F(x)=a * \log (x) \star \sin ((b * x)+c) \\
& +d^{*} x+f \\
& \text { Ch_sq }=5.00319\left(\mathrm{e}^{-07}\right) \quad \mathrm{F}(80)=0.022988 \\
& \mathrm{~F}(100)=0.024952 \quad \mathrm{~F}(120)=0.025835 \\
& 6 . F(x)=(a / \log (x)) * \sin ((b * x)+c) \\
& +d^{*} x+f \\
& \text { Ch_sq }=4.81392\left(\mathrm{e}^{-07}\right) \quad \mathrm{F}(80)=0.022989 \\
& \mathrm{~F}(100)=0.024713319 \quad \mathrm{~F}(120)=0.026005255
\end{aligned}
$$

\section{Choice of best fit for Max_CBR_Dist parameter a}

The equation in part 6 above has been selected because of smallest ch_sq and good extendability over larger node numbers. The parameters obtained for best fit are:

$\mathrm{a}=-0.00124785, \mathrm{~b}=0.497044, \mathrm{c}=4.15376, \mathrm{~d}=$ $8.12323\left(\mathrm{e}^{-05}\right), \mathrm{f}=0.016472$ $\underline{2.2}$ Trend Analysis - Max_CBR_Dist parameter " $b$ ".

Here also, the trend observed is an oscillation along a straight line with positive gradient and not along a horizontal line.

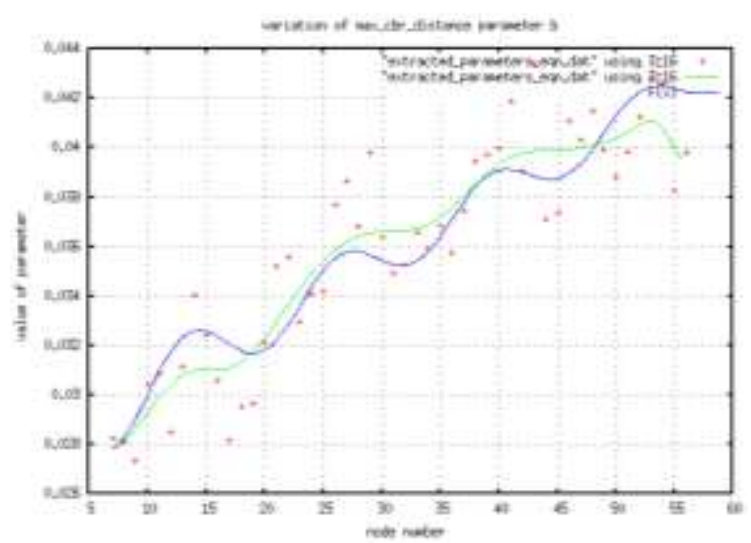

Figure 2: Max_CBR_Dist parameter b

The potentially applicable equations are:

$$
\begin{array}{rl}
\text { 1. } F(x)=d * x+f & \\
\text { Ch_sq }=4.28629\left(e^{-06}\right) & F(80)=0.049199518 \\
F(100)=0.054652232 & F(120)=0.060104946 \\
\text { 2. } F(x)=(a / \log \quad(x)) \quad * \quad \sin \quad((b * x)+c) \\
+d^{*} x+f \\
\text { Ch_sq }=3.93354\left(e^{-06}\right) & F(80)=0.049235966 \\
F(100)=0.053961276 & F(120)=0.059335525
\end{array}
$$

\section{Choice of best fit for Max_CBR_Dist parameter b}

The equation in part 2 above has been selected because of smallest ch_sq and good extendability over larger node numbers. The parameters obtained for best fit are:

$\mathrm{a}=-0.00335011, \mathrm{~b}=0.488456, \mathrm{c}=4.33805, \mathrm{~d}=$ $0.000264877, \mathrm{f}=0.02763447$

\subsection{Trend Analysis - Max_CBR_Dist parameter “c”.} Generally the curve depicts an increasing tendency at a decreasing rate, i.e. characteristic of logarithmic trends.

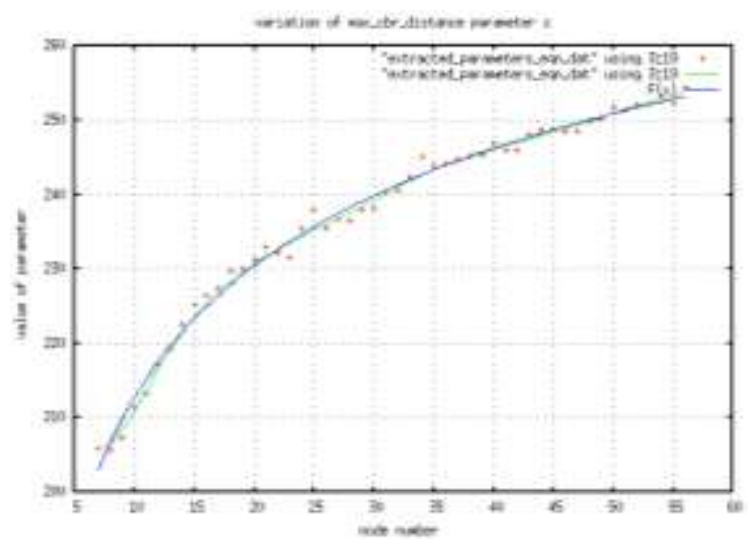

Figure 3: Max_CBR_Dist parameter c

The potentially applicable equations are: 


$$
\begin{aligned}
& \text { 1. } F(x)=a * \log (b * x)+c \\
& \text { Ch_sq }=1.95198 \quad \mathrm{~F}(80)=262.632001240 \\
& \mathrm{~F}(100)=267.923032 \quad \mathrm{~F}(120)=272.246119584 \\
& \text { 2. } F(x)=a * \log ((b * x)+c)+d \\
& \text { Ch_sq }=1.61504 \quad \mathrm{~F}(80)=261.220827 \\
& \mathrm{~F}(100)=265.990177737 \quad \mathrm{~F}(120)=269.867603795 \\
& \text { 3. } F(x)=a \star \log ((b * x)+c)+\left(d^{*} x\right) \\
& \text { Ch_sq }=1.58161 \quad \mathrm{~F}(80)=259.886218 \\
& \mathrm{~F}(100)=263.586175 \quad \mathrm{~F}(120)=266.267974 \\
& \text { 4. } F(x)=a * \log ((b * x)+c)+(d / x) \\
& \text { Ch_sq }=1.58252 \quad \mathrm{~F}(80)=260.983779 \\
& \mathrm{~F}(100)=265.641831 \quad \mathrm{~F}(120)=269.420161
\end{aligned}
$$

\section{Choice of best fit for Max_CBR_Dist parameter c}

The equation in part 3 above has been selected because of smallest ch_sq and good extendability over larger node numbers. The parameters obtained for best fit are:

$\mathrm{a}=24.3097, \mathrm{~b}=750.543, \mathrm{c}=-937.153, \mathrm{~d}=-0.090$ 0776

\section{Conclusion.}

This work of scrutiny was targeted at and has procured applicable models of trends of the parameters of equations for the metric Max_CBR_Dist in a MANET topography of $300 \times 300 \mathrm{~m}^{2}$. The models exposed in this current paper embodies mathematical equations of varying complexity. Such empirical information may drive the development of processing algorithms for simulator packages for more cultivated studies of MANETs. This empirical research was undertaken in gnuplot and criteria for selecting best fit are retained as reduced chi-square values and smoothest extendability experienced at higher node numbers.

The straightforward assumptions mentioned in previous paper [27] are re-applied here. Gnuplot is credited as significantly powerful for the purpose of this study.

Additional work identified here are: formulating a suitable method of predictability for metric Max_CBR_Dist and its trend and reporting specific observations of pertinent critical values identified.

\section{References}

[1] M. Kaleem GALAMALI, Assoc. Prof Nawaz MOHAMUDALLY, Towards Dependable Pervasive Systems-A Position and Vision Paper, CEET 2014

[2] M. Kaleem GALAMALI, Assoc. Prof Nawaz MOHAMUDALLY, Model of Energy Savings achievable with Location-aware Node-to-Node Transmission in UbiComp , CEET 2014

[3] M. Kaleem GALAMALI, Assoc. Prof Nawaz
MOHAMUDALLY, Model of Energy Savings achievable with Location-aware Node-to-Node Transmission in UbiComp Using Location Refresh Intervals, CEET 2014

[4] M. Kaleem GALAMALI, Assoc. Prof Nawaz MOHAMUDALLY, Model of Energy Savings achievable with Location-aware Transmission in UbiComp Using Relays, CEET 2014

[5] M. Kaleem GALAMALI, Assoc. Prof Nawaz MOHAMUDALLY, Mathematical modeling of need of exact number of relays to ensure seamless mobility in mobile computing, CEET 2014

[6] M. Kaleem GALAMALI, Assoc. Prof Nawaz MOHAMUDALLY, Modelling of need for multiple relays for ensuring seamless mobility, CEET 2014

[7] M. Kaleem GALAMALI, Assoc. Prof Nawaz MOHAMUDALLY, Investigation of prominence of placements of relays in a ubicomp topography,

[8] M. Kaleem GALAMALI, Assoc. Prof Nawaz MOHAMUDALLY, Model of energy savings achievable with location-aware transmission in ubicomp using optimised number of relays.

[9] M. Kaleem GALAMALI, Assoc. Prof Nawaz MOHAMUDALLY, Investigation of Prominence of Placements of Optimised Number of Relays in a Ubicomp Topography using Location-Aware Transmission, CEET 2015.

[10] M. Kaleem GALAMALI, Assoc. Prof Nawaz MOHAMUDALLY, Extending Node Battery Availability in Ubicomp with Location-Aware Transmission, CEET 2015.

[11] M. Kaleem GALAMALI, Assoc. Prof Nawaz MOHAMUDALLY, Extending Node Battery Availability in Ubicomp with Location-Aware Transmission using Location Refresh Intervals, CEET 2015.

[12] M. Kaleem GALAMALI, Assoc. Prof Nawaz MOHAMUDALLY, Extending Node Battery Availability in Ubicomp with Location-Aware Transmission using Uniformly Placed Relays, CEET 2015.

[13] M. Kaleem GALAMALI, Assoc. Prof Nawaz MOHAMUDALLY, Extending Node Battery Availability in Ubicomp with Location-Aware Transmission Using Optimally Placed Relays, CEET 2015.

[14] M. Kaleem GALAMALI, Assoc. Prof Nawaz MOHAMUDALLY, Model of Sender Node Energy Savings Achievable with Location-Aware MANET Transmission in Ubicomp. ACCN 2016

[15] M. Kaleem GALAMALI, Assoc. Prof Nawaz MOHAMUDALLY, Model of Overall Node Energy Savings Achievable with Location-Aware MANET Transmission in Ubicomp. ACCN 2016

[16] M. Kaleem GALAMALI, Assoc. Prof Nawaz MOHAMUDALLY, Model of Sender Node Extra Energy Savings Achievable in MANET Against Direct Node-toNode Transmission Using Location-Aware Transmission in Ubicomp. ACCN 2016

[17] M. Kaleem GALAMALI, Assoc. Prof Nawaz MOHAMUDALLY, Model of Overall Node Extra Energy Savings Achievable in MANET against Direct Node-toNode Transmission Using Location-Aware Transmission in Ubicomp. ACCN 2016

[18] M. Kaleem GALAMALI, Assoc. Prof Nawaz MOHAMUDALLY, Model of Energy Consumption Ratio Achievable in MANET Using Location-Aware Transmission in Ubicomp. ACCN 2016

[19] M. Kaleem GALAMALI, Assoc. Prof Nawaz MOHAMUDALLY, Model of Minimum Energy Consumption Ratio Achievable in MANET Using LocationAware Transmission in Ubicomp. ACCN 2016

[20] M. Kaleem GALAMALI, Assoc. Prof Nawaz MOHAMUDALLY, Model of Maximum Energy Consumption Ratio Achievable in MANET Using LocationAware Transmission in Ubicomp. ACCN 2016

[21] M. Kaleem GALAMALI, Assoc. Prof Nawaz MOHAMUDALLY, Model of Overall Energy Consumption Fairness Ratio Achievable in MANET Using Location-

Aware Transmission in Ubicomp. ACCN 2016

[22] M. Kaleem GALAMALI, Assoc. Prof Nawaz 
MOHAMUDALLY, Model of Overall Energy Consumption Fairness Proportion Achievable in MANET Using LocationAware Transmission for Ubicomp, CEET 2016

[23] M. Kaleem GALAMALI, Assoc. Prof Nawaz MOHAMUDALLY, Model of Minimum Fairness Proportion Achievable in MANET Using Location-Aware Transmission for Ubicomp, CEET 2016

[24] M. Kaleem GALAMALI, Assoc. Prof Nawaz MOHAMUDALLY, Model of Maximum Fairness Proportion Achievable in MANET Using Location-Aware Transmission for Ubicomp, CEET 2016

[25] M. Kaleem GALAMALI, Assoc. Prof Nawaz MOHAMUDALLY, Model of Sender Fairness Proportion Achievable in MANET Using Location-Aware Transmission for Ubicomp, CEET 2016

[26] M. Kaleem GALAMALI, Assoc. Prof Nawaz MOHAMUDALLY, Model of Distance Travelled by packets in MANETs using Location-Aware Transmission for Ubicomp, CEET 2016

[27] M. Kaleem GALAMALI, Assoc. Prof Nawaz MOHAMUDALLY, Model of Maximum CBR Distance Travelled by packets in MANETs using Location-Aware Transmission for Ubicomp, CEET 2016

[28] M. Kaleem GALAMALI, Assoc. Prof Nawaz MOHAMUDALLY, Model of Minimum CBR Distance Travelled by packets in MANETs using Location-Aware Transmission for Ubicomp, CEET 2016

[29] M. Kaleem GALAMALI, Assoc. Prof Nawaz MOHAMUDALLY, Model of Range CBR Distance Experienced by Transmissions in MANETs using LocationAware Transmission for Ubicomp, CEET 2016

[30] M. Kaleem GALAMALI, Assoc. Prof Nawaz MOHAMUDALLY, Trend Analyses of Parameters of Equations for Sender Node Energy Savings Achievable in ubicomp MANETs using Location-Aware Transmission, ACCN 2017.

[31] M. Kaleem GALAMALI, Assoc. Prof Nawaz MOHAMUDALLY, Trend Analyses of Parameters of Equations for Overall Node Energy Savings Achievable in ubicomp MANETs using Location-Aware Transmission, ACCN 2017.

[32] M. Kaleem GALAMALI, Assoc. Prof Nawaz MOHAMUDALLY, Trend Analyses of Parameters of Equations for Sender Node Extra Energy Savings Achievable in MANET against Direct Node-to-Node Location-Aware Transmission, ACCN 2017

[33] M. Kaleem GALAMALI Assoc Prof Nawaz MOHAMUDALLY, Trend Analyses of Parameters of Equations for Overall Nodes Extra Energy Savings Achievable in MANET against Direct Node-to-Node Location-Aware Transmission, ACCN 2017

[34] M. Kaleem GALAMALI, Assoc. Prof Nawaz MOHAMUDALLY, Trend Analyses of Parameters of Equations for Energy Consumption Ratio Achievable in Ubicomp MANET Using Location-Aware Transmission, ACCN 2017

[35] M. Kaleem GALAMALI, Assoc. Prof Nawaz MOHAMUDALLY, Trend Analyses of Parameters of Equations for Minimum Energy Consumption Ratio Achievable in Ubicomp MANETs Using Location-Aware Transmission, ACCN 2017

[36] M. Kaleem GALAMALI, Assoc. Prof Nawaz MOHAMUDALLY, Trend Analyses of Parameters of Equations for Maximum Energy Consumption Ratio Achievable in Ubicomp MANETs Using Location-Aware Transmission, ACCN 2017.

[37] M. Kaleem GALAMALI, Assoc. Prof Nawaz MOHAMUDALLY, Trend Analyses of Parameters of Equations for Overall Fairness Ratio Achievable in Ubicomp MANETs Using Location-Aware Transmission, ACCN 2017.

[38] M. Kaleem GALAMALI, Assoc. Prof Nawaz MOHAMUDALLY, Trend Analyses of Parameters of Equations for Energy Consumption Fairness Proportion Achievable in Ubicomp MANETs Using Location-Aware Transmission, CEET 2017

[39] M. Kaleem GALAMALI, Assoc. Prof Nawaz MOHAMUDALLY, Trend Analyses of Parameters of Equations for Minimum Fairness Proportion Achievable in
Ubicomp MANETs Using Location-Aware Transmission, CEET 2017

[40] M. Kaleem GALAMALI, Assoc. Prof Nawaz MOHAMUDALLY, Trend Analyses of Parameters of Equations for Maximum Fairness Proportion Achievable in Ubicomp MANETs Using Location-Aware Transmission, CEET 2017

[41] M. Kaleem GALAMALI, Assoc. Prof Nawaz MOHAMUDALLY, Trend Analyses of Parameters of Equations for Sender Fairness Proportion Achievable in Ubicomp MANETs Using Location-Aware Transmission, CEET 2017

[42] M. Kaleem GALAMALI, Assoc. Prof Nawaz MOHAMUDALLY, Trend Analyses of Parameters of Equations for Packets Per Distance Achievable in Ubicomp MANETs Using Location-Aware Transmission, CEET 2017

[43] Markus Bylund and Zary Segall, Towards seamless mobility with personal servers, 2004.

[44] Masugi Inoue, Mikio Hasegawa, Nobuo Ryoki and Hiroyuki Morikawa, Context-Based Seamless Network and Application Control, 2004

[45] Xiang Song, Umakishore Ramachandran, MobiGo: A Middleware for Seamless Mobility, College of Computing Georgia Institute of Technology, Atlanta, GA, USA, August 2007

[46] Budzisz, Ferrús, R., Brunstrom A., Grinnemo, K, Fracchia R., Galante, G., and Casadevall, F. Towards transport-layer mobility: Evolution of SCTP multihoming, March 2008

[47] Paul Dourish \& Genevieve Bell, Divining a digital future, 2011

[48] Xiang Song, Seamless Mobility In Ubiquitous Computing Environments, PhD Thesis, Georgia Institute of Technology, August 2008

[49] Kevin O Mahony, Jian Liang, Kieran Delaney, User-Centric Personalization and Autonomous Reconfiguration Across Ubiquitous Computing Environments, NIMBUS Centre Cork Institute of Technology, Cork, Ireland, UBICOMM 2012

[50] Pablo Vidales, Seamless mobility in $4 \mathrm{G}$ systems, Technical Report, University of Cambridge, Computer Laboratory, Number 656, November 2005

[51] João Pedro Sousa and David Garlan, Aura: An Architectura Framework for User Mobility in Ubiquitous Computing Environments, School of Computer Science, Carnegie Mellon University, USA, August 2002

[52] Dennis Lupiana, Ciaran O'Driscoll, Fredrick Mtenzi, Defining Smart Space in the Context of Ubiquitous Computing, Dublin Institute of Technology, Ireland, Special Issue on ICIT 2009 Conference - Web and Agent Systems, 2009

[53] N.S.V.Shet1, Prof.K.Chandrasekaran2 and Prof. K.C.Shet3, WAP Based Seamless Roaming In Urban Environment with Wise Handoff Technique, International Journal of UbiComp (IJU), Vol.1, No.4, October 2010

[54] Yipeng $\mathrm{Yu}$ Dan He Weidong Hua Shijian Li Yu Q Yueming Wang Gang Pan, FlyingBuddy2: A Braincontrolled Assistant for the Handicapped, Zhejiang University, UbiComp'12, September 5-8, 2012.

[55] Jing Su, James Scott, Pan Hui, Jon Crowcroft, Eyal de Lara Christophe Diot, Ashvin Goel, Meng How Lim, and Eben Upton, Haggle: Seamless Networking for Mobile Applications, 2007

[56] Rui Han, Moustafa M. Ghanem, Li Guo, Yike Guo*, Michelle Osmond, Enabling cost-aware and adaptive elasticity of multi-tier cloud applications, Future Generation Computer Systems, 2012

[57] Byrav Ramamurthy, K. K. Ramakrishnan , Rakesh K. Sinha, Cost and Reliability Considerations in Designing the NextGeneration IP over WDM Backbone Networks, 2012.

[58] Bhavish Aggarwal, Aditya Akella, Ashok Anand, Athula Balachandran, Pushkar Chitnis, Chitra Muthukrishnan, Ram Ramjee and George Varghese, EndRE: An End-System Redundancy Elimination Service for Enterprises, NSDI 2010, San Jose, CA

[59] Ashok Anand, Vyas Sekar and Aditya Akella, SmartRE: An Architecture for Coordinated Network-wide Redundancy Elimination, SIGCOMM 2009, Barcelona, Spain

[60] John Breeden II, "Smart-phone battery life could double without better batteries", Nov 14, 2012 
[61] Andy Boxall, "When will your phone battery last as long as your kindle", December 5, 2012.

[62] Imielinski, T. and Navas, J.C. (1999). GPS-based geographic addressing, routing, and resource discovery. Comms. ACM, Vol. 42, No. 4, pp. 86-92.

[63] Hightower, J. and Borriello, G. (2001). Location Systems for Ubiquitous Computing. IEEE Computer, Vol. 34, No. 8, August, pp. 57-66.

[64] Harter, A., Hopper, A., Steggles, P., Ward, A. and Webster, P. (2002). The Anatomy of a Context-Aware Application. Wireless Networks, Vol. 8, No. 2-3, Mar-May, pp. 187-197.

[65] Hightower, J., Brumitt, B. and Borriello, G. (2002). The Location Stack: A Layered Model for Location in Ubiquitous Computing. Proceedings of the 4th IEEE Workshop on Mobile Computing Systems \& Applications (WMCSA 2002), Callicoon, NY, USA, June, pp. 22-28.

[66] Graumann, D., Lara, W., Hightower, J. and Borriello, G. (2003). Real-world implementation of the Location Stack: The Universal Location Framework. Proceedings of the 5th IEEE Workshop on Mobile Computing Systems \& Applications (WMCSA 2003), Monterey, CA, USA, October, pp. 122-128.

[67] Ko, Y., \& Vaidya, N. H. (2000). Location-aided routing (LAR) in mobile ad hoc networks. Wireless Networks, 6(4), 307-321.

[68] Liao, W.-H., Tseng, Y.-C., \& Sheu, J.-P. (2001). GRID: a fully location-aware routing protocol for mobile ad hoc networks. Telecommunication Systems, 18(1), 37-60.

[69] Kuhn, F., Wattenhofer, R., Zhang, Y., \& Zollinger, A. (2003). Geometric ad-hoc routing: of theory and practice. In Proceedings of the ACM (PODC'03) (pp. 63-72).

[70] Jiang, X., \& Camp, T. (2002). Review of geocasting protocols for a mobile ad hoc network. In Proceedings of the Grace Hopper Celebration (GHC).

[71] Ko, Y. \& Vaidya, N. H. (1999). Geocasting in mobile ad hoc networks: location-based multicast algorithms. In Proceedings of the IEEE (WMCSA'99) (pp. 101).

[72] Mauve, M., Fuler, H., Widmer, J., \& Lang, T. (2003). Position-based multicast routing for mobile ad-hoc networks (Technical Report TR-03-004). Department of Computer Science, University of Mannheim.

[73] Xu, Y., Heidemann, J., \& Estrin, D. (2001). Geographyinformed energy conservation for adhoc routing. In Proceedings of the ACM/IEEE (MOBICOM'01) (pp. 70-84).

[74] Hu, Y.-C., Perrig, A., \& Johnson, D. (2003). Packet leashes: a defense against wormhole attacks in wireless ad hoc networks. In Proceedings of the INFOCOM' 03 (pp. 19761986).

[75] Patwari, N., Hero III, A. O., Perkins, M., Correal, N. S., \& O'Dea, R. J. (2003). Relative location estimation in wireless sensor networks. IEEE Transactions on Signal Processing, 51(8), 2137-2148.

[76] Baldauf, M., Dustdar, S., \& Rosenberg, F. (2007). A Survey on Context Aware Systems. International Journal of Ad Hoc and Ubiquitous Computing, Inderscience Publishers. forthcoming. Pre-print from: http://www.vitalab.tuwien.ac.at/ florian/papers/ijahuc2007.pdf

[77] Hong, D., Chiu, D.K.W., \& Shen, V.Y. (2005). Requirements elicitation for the design of context-aware applications in a ubiquitous environment. In Proceedings of ICEC'05 (pp. 590-596).

[78] Neeraj Tantubay, Dinesh Ratan Gautam and Mukesh Kumar Dhariwal, A Review of Power Conservation in Wireless Mobile Ad hoc Network (MANET)", International Journal of computer Science Issues, Vol 8, Issue 4, No 1, July 2011.

[79] Wenrui Zhao, Mostafa Ammar and Ellen Zegura, "A Message Ferrying Approach for Data Delivery in Sparse Mobile Ad Hoc Networks", MobiHoc'04, May 24-26, 2004, Roppongi, Japan.
About Author (s):

Associate Professor Nawaz Mohamudally works at University of Technology, Mauritius (UTM) and has undertaken supervision of $\mathrm{MPhil} / \mathrm{PhD}$ Students for many years.

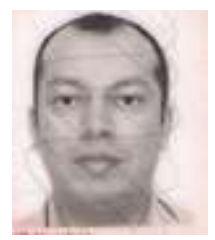

M. Kaleem Galamali is a part-time student (achieved M Phil Transfer on 28.10.2014, currently $\mathrm{PhD}$ student) at UTM under supervision of A.P. Nawaz Mohamudally. 